Summer 2015

\title{
Law, Fiscal Federalism, and Austerity
}

R. Daniel Kelemen

Rutgers University, dkelemen@polisci.rutgers.edu

Follow this and additional works at: https://www.repository.law.indiana.edu/ijgls

Part of the European Law Commons, International Law Commons, and the Transnational Law

\section{Commons}

\section{Recommended Citation}

Kelemen, R. Daniel (2015) "Law, Fiscal Federalism, and Austerity," Indiana Journal of Global Legal Studies: Vol. 22 : Iss. 2 , Article 5.

Available at: https://www.repository.law.indiana.edu/ijgls/vol22/iss2/5

This Symposium is brought to you for free and open access by the Law School Journals at Digital Repository @ Maurer Law. It has been accepted for inclusion in Indiana Journal of Global Legal Studies by an authorized editor of Digital Repository @ Maurer Law. For more information, please contact rvaughan@indiana.edu.

\section{$\Psi$}

JEROME HALL LAW LIBRARY

INDIANA UNIVERSITY

Maurer School of Law
Bloomington 


\title{
Law, Fiscal Federalism, and Austerity
}

\author{
R. DANIEL KELEMEN ${ }^{\star}$
}

ABSTRACT

In response to the Eurozone crisis, European Union leaders have undertaken a number of dramatic reforms, including the imposition of a new regime for fiscal governance of Eurozone Member States. The 2012 Fiscal Compact Treaty, one of the lynchpins of this package of reforms, requires states to incorporate judicially enforceable balanced-budget rules into national law. This article explores this effort to judicialize austerity in the European Union, focusing on two interrelated sets of questions. First, why did EU leaders turn to the courts and ask them to become the stewards of fiscal discipline, and second, should we expect the effort to judicialize fiscal discipline through the Fiscal Compact to work? I argue that after the failure of the Maastricht Eurozone governance regime, Member State governments concluded that the enforcement of fiscal rules must be shielded from political interference and entrenched at the national level, where national courts could assure that EU rules were respected by reluctant governments. Nevertheless, I conclude that these efforts will fail because they are based on a misunderstanding of when and how fiscal rules are actually enforced. The vague character of the balanced budget rules adopted in the Fiscal Compact Treaty along with other background conditions in the structure of the Eurozone mean that the rules are unlikely to be enforced.

\section{INTRODUCTION}

The Eurozone crisis exposed, in dramatic fashion, the inadequacies of the economic governance regime put in place when the Euro common currency was created. In response to the crisis, European Union (EU) leaders have undertaken a number of dramatic reforms including the establishment of a permanent bailout fund, 1 the partial (and ongoing)

* R. Daniel Kelemen is a Professor of Political Science at Rutgers University.

1. The establishment of this fund, the European Stability Mechanism (ESM), is discussed below. The ESM was created through an intergovernmental treaty signed by

Indiana Journal of Global Legal Studies Vol. 22 \#2 (Summer 2015) (C) Indiana University Maurer School of Law 
construction of a banking union, ${ }^{2}$ and the imposition of a new regime for fiscal governance of Eurozone Member States. The Fiscal Compact constitutes one of the lynchpins of this package of reforms. ${ }^{3}$ The core of the Fiscal Compact involves an effort to judicialize austerity by requiring states to incorporate judicially enforceable balanced-budget rules into national law. ${ }^{4}$ Of course, fiscal rules had been part of Eurozone governance from the outset. The Maastricht Treaty, which created the original legal framework for the Eurozone common currency area, had established limits on deficit and debt levels for Eurozone states. ${ }^{5}$ In 1997, to strengthen and reinforce these fiscal supervision and enforcement provisions of the Maastricht Treaty, the European Union adopted the Stability and Growth Pact (SGP). ${ }^{6}$ However, this "Maastricht regime" of fiscal governance left the enforcement of these rules mostly up to political actors in the Commission and Council-with a limited role for European courts. The Maastricht Treaty began to break down in the mid-2000s and was abandoned altogether in the midst of the crisis. ${ }^{7}$ In redesigning Eurozone governance with the 2012

Eurozone governments on February 2, 2012. See Treaty Establishing the European Stability Mechanism, art. 3, Feb. 2, 2012, http://europa.eu/rapid/press-release_DOC-123_en.htm (multilateral treaty establishing the ESM as a means "to safeguard the financial stability of the euro area as a whole and of its Member States").

2. See David Howarth \& Lucia Quaglia, The Steep Road to European Banking Union: Constructing the Single Resolution Mechanism, 52 J. COMMON MARKET STUD. 125, 125 (2014) (discussing the purpose and reasoning behind the construction of a European banking union, including to "restore confidence in European banking systems weakened by ... the international financial crisis and the sovereign debt crisis").

3. Formally, the Treaty on Stability, Coordination and Governance in the Economic and Monetary Union (TSCG), which took effect on January 1, 2013. Treaty on Stability, Coordination and Governance in the Economic and Monetary Union, Mar. 2, 2012, http://europa.eu/rapid/press-release_DOC-12-2_en.htm [hereinafter TSCG]. On the TSCG, see generally Paul Craig, The Stability, Coordination and Governance Treaty: Principle, Politics and Pragmatism, 37 EUR. L. REV. 231 (2012) (discussing the role of the TCSG as one of many EU responses to the global financial crisis and ensuing crisis with the euro).

4. TSCG, supra note 3, art. 3. See infra Part III for further discussion of the TSCG.

5. Formally, the Treaty on European Union (TEU), which took effect on November 1, 1993. See Treaty on European Union, Feb. 7, 1992, art. 104c, Protocol on the Excessive Deficit Procedure, 31 I.L.M. 247 (discussing deficit and debt rules and enforcement mechanisms) [hereinafter TEU].

6. The SGP took the form of two Council Regulations. For discussion of the aims of Council Regulations and their relationship with the SGP, see Council Regulation 1466/97, on the Strengthening of the Surveillance of Budgetary Positions and the Surveillance and Coordination of Economic Policies, 2d recital, 1997 O.J. (L 209) 1 (EC); Council Regulation 1467/97, on Speeding Up and Clarifying the Implementation of the Excessive Deficit Procedure, 3d recital, 1997 O.J. (L 209) 6 (EC) [hereinafter Council Regulations].

7. See generally R. Daniel Kelemen, Europe's New Normal, ForeIGN AFFaIRS (May 16, 2012), http://www.foreignaffairs.com/articles/137642/r-daniel-kelemen/europes-new- 
Fiscal Compact, EU leaders sought to reduce political discretion and to call on courts to enforce deficit and debt limits on governments.

This article explores these recent efforts to judicialize austerity in the European Union, focusing on two interrelated sets of questions. First, in reforming Eurozone governance, why did EU leaders turn to the courts and ask them to become the stewards of fiscal discipline? I argue that when establishing a common currency, the European Union faced a moral hazard problem that is common to federal and quasifederal systems: the European Union needed to find a credible way to discourage Member States from building up unsustainable debts and then turning to the European Union for a bailout. ${ }^{8}$ As mentioned above, the Maastricht Treaty and the Stability and Growth Pact included a number of provisions designed to address this issue, but EU member governments eventually disregarded these provisions. From the failure of the Maastricht regime, Member State governments took the lesson that the enforcement of fiscal rules must be shielded from political interference and entrenched at the national level. Following a pattern of governance-"Eurolegalism"9_that is common in many fields of EU

normal (discussing the impact of the financial crisis on the European Union and considering proposed solutions).

8. On the notion of moral hazard in the context of fiscal federalism see generally Torsten Persson \& Guido Tabellini, Federal Fiscal Constitutions: Risk Sharing and Moral Hazard, 64 ECONOMETRICA 623 (1996) (analyzing the tradeoff between risk-sharing and moral hazard in fiscal federalism by contrasting the fiscal constitutions of vertically and horizontally ordered systems); Jonathan Rodden, The Dilemma of Fiscal Federalism, 46 AM. J. POL. SCI. 670 (2002) (analyzing cross-national data to discuss the effects of fiscal and political institutions on the performance of subnational governments); Jürgen von Hagen \& Barry Eichengreen, Federalism, Fiscal Restraints and European Monetary Union, 86 AM. ECON. REV. 134 (1996) (discussing the interaction of fiscal restrictions such as the Excessive Deficit Procedure with federalism in the EU context); Erik Wibbels, Federalism and the Politics of Macroeconomic Policy and Performance, 44 AM. J. POL. SCI. 687 (2000) (arguing that macroeconomic and fiscal imbalances in developing federal nations are influenced by political and fiscal institutions that create incentives for subnational governments to avoid fiscal adjustment). On the role of moral hazard in the particular context of Eurozone governance see generally Erik Jones, Liberalized Capital Markets, State Autonomy, and European Monetary Union, 42 EUR. J. PoL. RES. 111 (2003) (discussing how EU monetary union has increased macroeconomic flexibility with varying impacts on financial volatility in different countries); Erik Jones, Merkel's Folly, 52 SURVIVAL 21, 23 (2010) [hereinafter Jones, Merkel's Folly] (discussing the role of moral hazard in contributing to the 2009 fiscal crisis in Greece and the subsequent impact of this crisis on the rest of the European Union); R. Daniel Kelemen \& Terence K. Teo, Law, Focal Points and Fiscal Discipline in the United States and the European Union, 108 AM. POL. SCI. REV. 355 (2014) (applying analysis of fiscal discipline in the United States to the European Union to argue that balanced budget rules can restrain sovereign debt and lower sovereign borrowing costs, even in the absence of judicial enforcement).

9. R. DANiEl Kelemen, EUROlegalism: The TRansformation OF LAW and REGULATION IN THE EUROPEAN UNION 7-8 (2011). 
policy making, they sought to harness national courts to act as agents of the European Union, enforcing its policies on reluctant governments. Thus, the 2012 Fiscal Compact sought to judicialize fiscal policy by empowering national courts to enforce deficit and debt limits.

Second, the paper explores whether the effort to judicialize fiscal discipline through the Fiscal Compact will work. I argue that these efforts will fail because they are based on a misunderstanding of how fiscal rules actually operate. ${ }^{10}$ In practice, courts rarely enforce balanced budget rules, such as those at the heart of the Fiscal Compact. When governments respect such rules they do so not out of concern about judicial enforcement, but due to concern about bond market reactions to violation of the rules. For bond markets to enforce fiscal rules effectively, however, the rules must be very clear. The vague character of the balanced budget rules adopted in the Fiscal Compact ${ }^{11}$ along with other background conditions in the structure of the Eurozone such as the fact that the European Union has established a permanent bailout fund (the European Stability Mechanism), ${ }^{12}$ mean that bond markets are unlikely to effectively enforce them.

The remainder of the article is divided into four parts. Part I examines the background conditions and political context that led to the failure of the original Maastricht Treaty-based regime for Eurozone governance. Part II explains why EU leaders reacted to the failure of the Maastricht regime by embracing a strategy that would have courts enforce fiscal discipline. Part III explains why the effort to judicially mandate compliance with fiscal policy by including legally enforceable balanced budget rules in the Fiscal Compact is likely to prove ineffective. Finally, the conclusion asks what broader lessons can be drawn about the relationship between law, fiscal federalism, and austerity in the European Union and beyond.

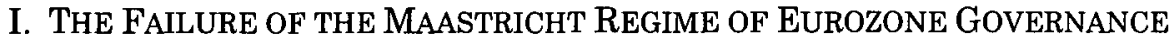

From its inception, the Eurozone faced a moral hazard problem common to any federal or nonfederal system that shares a common currency and a single market but in which Member States control substantial aspects of fiscal policy. Any such system must find a credible

10. See Kelemen \& Teo, supra note 8, at 365 (arguing that the EU's effort to judicialize the fiscal process will fail).

11. TSCG, supra note 3 , art. 3 .

12. See Bruno de Witte, The European Treaty Amendment for the Creation of a Financial Stability Mechanism, EUR. POL'Y ANALYSIS, June 2011, at 5-6. 
way to discourage states from building up unsustainable debt loads. ${ }^{13}$ Problems may occur when one or more state governments find themselves saddled with an unsustainable debt burden and default, generating a host of negative spillover effects for other states or for the federal government. The high spillover costs of a state default may prompt the federal government to intervene to bail out the struggling state. But a situation of moral hazard arises if the federal level is perceived as guaranteeing the solvency of individual states. State governments may be tempted to borrow excessively-and private sector lenders may be tempted to indulge them-because all involved believe that the federal government will bail states out if their debt becomes unsustainable. Likewise, even fiscally prudent states may be tempted to regulate their banking sectors in a lax manner, believing that if lax regulation leads to a financial crisis that threatens the solvency of the state, the federal government will bail out the state.

One option for how the federal system can address this moral hazard problem is for the federal government to establish a credible commitment not to bail out state governments. If the federal level can establish a credible commitment that it will not bail out insolvent states, then neither states nor bond markets will act in anticipation of bailouts. The United States chose this path in the early 1840s when a number of states faced debt crises. ${ }^{14} \mathrm{~A}$ brief diversion into the history of U.S. fiscal federalism helps to underline one viable path to addressing the moral hazard that the European Union has not taken.

In the $1820 \mathrm{~s}$ and $1830 \mathrm{~s}$, a number of state governments borrowed heavily to finance infrastructure projects. When a financial crisis in 1839 was followed by a severe economic downturn, a number of state governments could no longer service their debts. ${ }^{15}$ They turned to the federal government for assistance. Indeed, there was a precedent for federal assistance to struggling states, as the federal government in 1790 had agreed to assume the debt that states had accumulated in the course of the Revolutionary War. ${ }^{16}$ But unlike in 1790, where the debt

13. See also sources cited supra note 8 (discussing strategies for, and the importance of, federal systems limiting debt loads).

14. See generally William B. English, Understanding the Costs of Sovereign Default: American State Debts in the 1840's, 86 AM. ECON. REV. 259 (1996) (scrutinizing the defaults of the United States in the 1840s); Arthur Grinath, III et al., Debt, Default and Revenue Structure: The American State Debt Crisis in the Early 1840s, 1 (Nat'l Bureau of Econ. Res. Working Paper Series on Hist. Factors in Long Run Growth, Paper No. 97, 1997) (examining the cause of and remedy for the United States' 19th Century debt crisis).

15. John Joseph Wallis, What Caused the Crisis of 1839?, 1 (Nat'l Bureau of Econ. Res. Working Paper Series on Hist. Factors in Long Run Growth, Paper No. 133, 2001).

16. Harold James, Alexander Hamilton's Eurozone Tour, PROJECT SYNDICATE (Mar. 5, 2012), http://www.project-syndicate.org/commentary/alexander-hamilton-s-Eurozone-tour. 
had been incurred in a common military struggle, this time state debts were the result of infrastructure investments and the federal government responded differently. In 1841, the federal government flatly refused to finance the debt several states had accumulated, and as a result, eight states and the territory of Florida defaulted. ${ }^{17}$

The federal government's willingness to allow states to default proved a defining event in the history of U.S. fiscal federalism. Allowing several constituent states in the federation to default-with all the economic pain and risk that entailed-established the federal government's commitment to not bail out insolvent states as credible. Creditors initially shunned the insolvent state governments. The states then undertook dramatic reforms to reestablish their credibility vis-àvis lenders and regain access to the credit markets. Some states raised tax rates or introduced altogether new taxes-such as property taxesto create new revenue streams that would bring their fiscal house in order. The defaulting states introduced balanced budget laws, in many cases entrenching them in their state constitutions. The states imposed the rules on themselves in an effort to tie their own hands and regain the confidence of wary investors to bring their borrowing costs down. ${ }^{18}$ Eventually forty-nine of the fifty states imposed such rules on themselves even in the absence of any federal mandate to do so. ${ }^{19}$

The architects of the Maastricht regime of Eurozone governance recognized the moral hazard described above and put in place a set of rules designed to address it. First, the Maastricht Treaty included a nobailout clause (Article 104b, now Article 125 of the Treaty of the Functioning of the European Union (TFEU)), which stipulated that neither the Community nor any individual Member State could bailout (i.e., assume the debts of) another Member State.20 Second, the Maastricht Treaty required that Member States avoid excessive

17. English, supra note 14, at 262; Grinath, IIl et al., supra note 14, at 4.

18. English, supra note 14 , at $259-60$.

19. See Federico Fabbrini, The Fiscal Compact, the "Golden Rule," and the Paradox of European Federalism, 36 B.C. INT'L \& CoMP. L. REV. 1 (2013) (emphasizing that in contrast to the situation in the European Union, the individual states of the United States adopted balanced budget rules without being mandated to do so by the central government).

20. TEU, supra note 5, art. 104b ("The Union shall not be liable for or assume the commitments of central governments, regional, local or other public authorities, other bodies governed by public law, or public undertakings of any Member State, without prejudice to mutual financial guarantees for the joint execution of a specific project. A Member State shall not be liable for or assume the commitments of central governments, regional, local or other public authorities, other bodies governed by public law, or public undertakings of another Member State, without prejudice to mutual financial guarantees for the joint execution of a specific project"). 
government deficits, ${ }^{21}$ and put in place a detailed, punitive excessive deficit procedure. ${ }^{22}$ In short, the Excessive Deficit Procedure required that annual deficits should not exceed 3 percent of gross domestic product (GDP) and that accumulated debt should not exceed 60 percent of GDP, though it included some qualifications and exceptions to these rules that rendered them more flexible. ${ }^{23}$ The Excessive Deficit Procedure also established a lengthy, multistage, and highly politicized enforcement process. ${ }^{24}$ At the conclusion of that process, if a state refused to comply with the recommendations of the Council and rectify its excessive deficit, the Council could, if it chose to do so, "require the Member State concerned to make a non-interest-bearing deposit of an appropriate size with the Community until the excessive deficit has, in the view of the Council, been corrected";25 or the Council could, "impose fines of an appropriate size." 26 As noted above, EU leaders moved to bolster these fiscal provisions of the Maastricht Treaty in 1997 by adopting the SGP. ${ }^{27}$

Thus before the launch of the euro currency, the European Union had-at least on paper and in principle-implemented a system of governance designed to limit the moral hazard associated with excessive Member State deficits. But the application of this system in practice fell far short of the principles laid down in the Treaty text, and when crisis struck, the Maastricht regime of Eurozone governance was largely abandoned as the European Union stepped in to bail out struggling states. Contrasting the U.S. experience in the early 1840 s with the European Union's experience in the last five years underscores that, for a "no-bailouts" commitment to be credible, words on paper alone are not enough-indeed, they may not be necessary. Rather, the key to credibility is that the federal government must demonstrate in practice that it is willing to allow states to default.

21. See Id. art. 104c.

22. See the procedure elaborated in TEU, Protocol (No. 12) on the Excessive Deficit Procedure, Feb. 7, 1992.

23. See Id. art. $104 \mathrm{c}(2)$ (a) (suggesting that exceptions to the deficit rules could be made if, "the ratio has declined substantially and continuously and reached a level that comes close to the reference value; or, alternatively, the excess over the reference value is only exceptional and temporary and the ratio remains close to the reference value"). See also Id. art. $104 \mathrm{c}(2)$ (b) (suggesting that exceptions to the deficit rules could be made if, "the ratio is sufficiently diminishing and approaching the reference value at a satisfactory pace").

24. See Id. art. 104c(3)-(13).

25. See Id. art. $104 \mathrm{c}(11)$.

26. Id.

27. See Council Regulations, supra note 6 . 
The rules on excessive deficit and debt set out in the Maastricht Treaty and the SGP were the first elements of the Maastricht regime to crumble. In one of the great ironies of the Eurozone saga, it was Germany that played a decisive role in gutting the very rules it had been so adamant about putting in place. In 2003, the European Commission launched the Excessive Deficit Procedure against Germany and France, two countries that were clearly in violation of the rules stipulated in the SGP. ${ }^{28}$ Yet, when the time came for other Member States in the European Council to back the Commission's recommendations and pursue enforcement of the Excessive Deficit Procedure, they balked. On November 25, 2003, at the 2,546th meeting of the Council of Ministers, ${ }^{29}$ the SGP and its Excessive Deficit Procedure effectively died. At that meeting, a majority of Member States backed Germany and France and agreed to suspend excessive deficit proceedings against them. These Member States chose simply to publish a set of "Political Conclusions"-recommendations for further actions to assure the sustainability of public finances in the two countries. ${ }^{30}$ The gutting of the SGP was formalized in 2005 when the Council adopted a pair of Regulations that substantially loosened the requirements of the SGP and Excessive Deficit Procedure. ${ }^{31}$

The next pillar of the Maastricht governance regime to collapse was the no-bailout clause. Again, and with equal irony, the German government played a key role in undermining the credibility of this rule. The story of the demise of the no-bailout clause began in October of 2008, when the Greek government first restated its deficit figuresdramatically increasing them. Concerns about mounting debt in Greece, along with concerns about repercussions from the U.S. financial crisis,

28. Stephen Castle, EU Rebukes Germany over Euro Rules, THE INDEPENDENT, Jan. 9, 2003, available at http://www.independent.co.uk/news/world/europe/eu-rebukes-germanyover-euro-rules-123454.html; Ambrose Evans-Pritchard, France and Germany Smash Euro Pact, THE TELEGRAPH, Nov. 26, 2003, available at http:/www.telegraph.co.uk/ finance/2870055/France-and-Germany-smash-Euro-pact.html. The Commission had warned it would initiate these sanctions already in 2002. See Budget Sanctions Hit Germany and France, BBC NEwS, Nov. 19, 2002, available at http://news.bbc.co.uk/2/hi/ business/2492339.stm.

29. In this case, the Council of Ministers was meeting as the Economic and Financial Affairs Council.

30. Barbara Dutzler \& Angelika Hable, The European Court of Justice and the Stability and Growth Pact - Just the Beginning?, 9 EUR. INTEGRATION ONLINE PAPERS 1 (2005); MARTIN HEIPERTZ \& AMY VERDUN, States, Intergovernmentalism and Negotiating in the SGP, in Ruling Europe: The Politics of the Stability aNd Growth PaCt (2010).

31. See Council Regulation No. 1055/2005, 2005 O.J. (L 174) 1 (EC) (strengthening the surveillance of budgetary positions and the surveillance and coordination of economic policies); Council Regulation No. 1056/2005, 2005 O.J. (L 174) 5 (EC) (speeding up and clarifying the implementation of the excessive deficit procedure). 
led investors to demand higher yields on Greek bonds. After adopting the euro, Greece had enjoyed years of low borrowing costs nearly at parity with those of Germany, but in the month after its budget restatement the interest rate spread between Greece and Germany increased dramatically-from eighty-nine basis points on October 1, 2008 to 165 basis points by the end of that month. ${ }^{32}$ Greece's increased borrowing costs reflected mounting concerns in the markets about the risk that it might default on its debt-a clear possibility under the Maastricht "no-bailout" regime. By early 2009, investors grew more wary and the differential between Germany's borrowing costs and those of Greece and other peripheral Eurozone economies continued to increase. In a form of self-fulfilling prophecy, these increasing borrowing costs themselves posed a risk to the solvency of Greece and other peripheral Eurozone economies. In February 2009, German Finance Minister Peer Steinbrück stepped into the fray, stating publicly that "the euro-region treaties don't foresee any help for insolvent countries, but in reality the other states would have to rescue those running into difficulty." 33 Initially, his statement had the intended effect: it calmed markets and brought down Greece's borrowing costs. At the same time, Steinbrück's promise that no Eurozone state would be allowed to go bankrupt effectively killed the Maastricht Treaty's no-bailout pledge.

By the end of 2009, concerns over Greece resurfaced. The Greek government again restated its deficits in October 2009, this time revealing that the levels were far higher than permitted under the Maastricht rules. ${ }^{34}$ At the same time, a change in the German coalition government brought in a new finance minister, calling into question whether Steinbrück's promise of assistance for states facing a debt crisis would be honored. German Chancellor Angela Merkel fed the flames at the March 2010 European Council summit by declaring that Germany would only provide support to another Member State if it lost access to private capital markets-in other words after it went bankrupt, but not before. With this declaration, private capital flowed out of Greece and Greek borrowing costs soared, finally leading Greece to seek a bailout from the European Union and International Monetary Fund (IMF). ${ }^{35}$

Working with IMF officials, EU leaders first put in place an ad hoc Hellenic Financial Stability Fund to support Greece and later established a larger European Financial Stability Facility (EFSF) to

32. Erik Jones, The Euro Versus the Markets, 55 ASPENIA 146, 149 (2012).

33. Rainer Buergin \& Holger Elfes, Steinbrueck Says Euro States May Bail Out Members (Update2), BLOOMBERG (Feb. 17, 2009, 11:12 AM), http://www.bloomberg.com/ apps/news?pid=newsarchive\&sid=aGX4UExx.jOk.

34. See TEU, supra note 5.

35. See Jones, Merkel's Folly, supra note 8, at 21-22. 
support other Member States should they face a debt crisis. ${ }^{36}$ Soon after Greece sought assistance, Ireland and Portugal turned to the EFSF for bailouts. Finally, in February 2011, EU leaders agreed to establish a permanent bailout fund, the European Stability Mechanism (ESM) to eventually replace the temporary EFSF. ${ }^{37}$ With the establishment of a permanent bailout fund in the ESM, the European Union formalized the burial of the no-bailout provisions of the Maastricht Treaty. The creation of the ESM was linked to the establishment of a new regime of fiscal governance that promised to enforce fiscal discipline strictly and to ensure financial stability. To understand that regime and the role balanced budget rules played in it, it is first important to consider precisely why the European Union chose to bail out struggling Eurozone states, rather than to let them default as had been pledged in the Maastricht Treaty-and as the United States had done in the $1840 \mathrm{~s}$.

The first consideration that drove EU leaders to renege on their "nobailout" pledge was fear of the repercussions of a disorderly Greek default. EU leaders feared that the default of even one small Member State, such as Greece, could have a domino effect, raising borrowing costs and leading to defaults and bank failures across peripheral Eurozone economies-with disastrous consequences for the Eurozone as a whole. ${ }^{38}$ If Greece defaulted-and possibly exited the euro-then bondholders in Portugal, Ireland, Spain, and elsewhere might worry about their country's potential for default and seek to unload their holdings. This trend would send borrowing costs soaring and could lead a series of countries to default. Likewise, savers across the more vulnerable economies on the periphery of the Eurozone, concerned that a financial crisis might bring down banks or that their savings might be redenominated in a new currency, would be tempted to transfer their funds to accounts in safer havens such as Germany. Such bank runs could prompt bank failures across the periphery. Fears of such contagion within the context of the integrated financial markets and integrated banking system that the European Union had created led its

36. See generally Ledina Gocaj \& Sophie Meunier, Time Will Tell: The EFSF, the ESM, and the Euro Crisis, 35 J. EUR. INTEGRATION 239, 240-47 (2013) (detailing the creation of the EFSF).

37. See de Witte, supra note 12.

38. For instance, on April 20, 2010, German Finance Minister Wolfgang Schäuble pleaded with German citizens to support a bailout of Greece. "We cannot allow the bankruptcy of a Euro member state like Greece to turn into a second Lehman Brothers,' he told Der Spiegel. 'Greece's debts are all in Euros, and it isn't clear who holds how much of those debts. The consequences of a national bankruptcy would be incalculable. Greece is just as systemically important as a major bank." Gary Dorsch, Could Greek Debt Tragedy Morph into a Lehman Meltdown Market Crash?, MARKET ORACLE (Apr. 28, 2010, 2:43 AM), marketoracle.co.uk/Article18997.html. 
leaders to conclude that the risks of Greek default were too high to countenance. ${ }^{39}$

The second set of considerations was more political, focusing on how the blame for bailouts and other crisis related measures would be apportioned. Financial institutions in core countries, such as Germany and France, held substantial portions of Greece's sovereign debt, and more generally they held substantial portfolios of sovereign debt and loans to countries across the periphery of the Eurozone. A disorderly default by Greece-particularly if it generated spillovers for other southern economies-could have threatened the solvency of banks in the core. The risk of such bank failures would have generated pressure on core governments to bail out their own banks.

So, Germany and other lender countries faced a choice that was not simply between providing bailouts to governments of peripheral Eurozone economies or not providing bailouts. Rather, it was a choice between bailing out peripheral governments or bailing out their own banks that were exposed to bad debt in those countries. For countries like Germany and France, it was politically more palatable to bail out debtor countries than to let them default and then have to bail out their own banks. ${ }^{40}$ This tendency was motivated by how the blame for bailouts is apportioned. When a creditor country bails out a debtor, voters tend to blame the debtor country-for example, when Germans criticized supposedly profligate and lazy Greeks for their financial crisis. ${ }^{41}$ By contrast, if a government bails out its own banks, voters are

39. The dynamics in the 1840 s United States were very different as nearly all the state bonds in question were held by European creditors, wholly outside the U.S. political system. While defaults by some U.S. states could have wreaked havoc on financial institutions in Europe, the defaults of individual states posed little direct risk to financial institutions in other U.S. states. In the European Union by contrast, financial institutions in fellow EU states held many of the bonds of other heavily indebted EU states. See English, supra note 14 , at 261.

40. As many commentators have noted, the bailouts extended to Greece and other countries on the Eurozone periphery were largely channeled through those governments to pay back debts to banks in Germany, France and other core countries. See, e.g., Ben Chu, Germany Is Not Bailing Out Europe, It Is Rescuing Itself, INDEPENDENT (July 5, 2012), http://www.independent.co.uk/news/business/comment/ben-chu-germany-is-notbailing-out-europe-it-is-rescuing-itself-7912743.html (discussing how Germany's decision to assist struggling nations was also done to help German banks); Gareth Gore \& Sudip Roy, German Banks Win Big from Spain Bailout, ReUTERS (June 29, 2012, 6:46 PM), http://in.reuters.com/article/2012/06/29/spain-germany-bailout-ifr-idINL6E8HTFC820120629 (describing how some of the biggest beneficiaries of the Spanish bank bailout were German banks).

41. See Yiannis Mylonas, Media and the Economic Crisis of the EU: The 'Culturalization' of a Systemic Crisis and Bild-Zeitung's Framing of Greece, 10 TRIPLEC: COGNITION, COMM., Co-OPERATION 646, 665-66 (2012) (describing the depictions of Greeks in the German media during the crisis). 
likely to blame that government for giving handouts to wealthy, irresponsible bankers. ${ }^{42}$

\section{The New Eurozone Governance REgime And THE TuRn to THE COURTS}

The foregoing considerations explain why EU Member States did not allow Greece or other beleaguered Member States to default, and why they instead established a permanent architecture for bailouts with the ESM. But providing bailouts without conditions would have only exacerbated the moral hazard problem, tempting Member States to build up unsustainable debts with the expectation they would be bailed out. There could be no bailouts without conditionality, so the EU money came with legally enforceable strings attached. At the behest of Germany and other lender countries, the European Union put in place a new regime of Eurozone fiscal governance. ${ }^{43}$ The new regime imposed balanced budget rules, which forced some states to pursue austerity. It backed these rules with the threat of judicial enforcement in an attempt to ensure that politicians would not block their enforcement as they had blocked enforcement of the SGP in the mid-2000s. ${ }^{44}$ In short, the judicial enforcement of austerity was the quid pro quo for the financial rescue of states on the verge of default.

The new regime was comprised of a number of legal instruments designed to strengthen budget discipline and to broaden the reach of macroeconomic policy coordination to cover economic imbalances beyond the fiscal domain. The surveillance and enforcement mechanisms of the SGP were strengthened with the so-called "six pack," a package of five regulations and one directive adopted in November $2011 .{ }^{45}$ But some EU

42. It is also important to note that if Germany or other creditor countries had bailed out their own banks directly, such payments would have added to their own country's sovereign debt. By contrast, when creditor countries extend long-term, below market rate loans to Greece or other debtor countries, which then use those loans to repay debts to banks in the core countries, these loans are not booked as losses in accounting terms and do not officially add to sovereign debt figures for the creditor countries. See Jacob Soll, Greece's Accounting Problem, N.Y. TIMES, Jan. 20, 2015, available at http://www. nytimes.com/2015/01/21/opinion/greeces-accounting-problem.html?_r=0.

43. See Kelemen, supra note 7.

44. See supra, Part I.

45. Council Regulation 1173/2011, 2011 O.J. (L 306) 1 (EU); Council Regulation 1174/2011, 2011 O.J. (L 306) 8 (EU); Council Regulation 1175/2011, 2011 O.J. (L 306) 12 (EU); Council Regulation 1176/2011, 2011 O.J. (L 306) 25 (EU); Council Regulation 1177/2011, 2011 O.J. (L 306) 33 (EU); Council Directive 2011/85/EU, 2011 O.J. 41 (EU); Later, the "six-pack" was supplemented by a pair of new regulations-the so-called "twopack'-that further enhanced EU supervision of Member state budgets. See Council 
leaders, above all German Chancellor Angela Merkel, saw such legislative changes alone as inadequate, and demanded that fiscal discipline be bolstered through an amendment of the EU Treaties. In early December 2011, Merkel and Nicolas Sarkozy, the French President, agreed to push for a revision of the EU treaties that would give EU authorities a more powerful role in approving national budgets and would demand that Member States enshrine automatic, "binding debt brakes" in national law-subject to ECJ oversight. ${ }^{46}$ After the U.K. government vetoed a revision of the EU Treaties in December 2011,47 leaders of Eurozone countries agreed that they would adopt an intergovernmental treaty outside the scope of EU law and leave it open to other EU Member States to join. Finally, on January 30, 2012, twenty-five member governments agreed to the terms of the Fiscal Compact, ${ }^{48}$ a new intergovernmental treaty outside the scope of EU law. ${ }^{49}$ This treaty was tied to the European Union's new bailout regime because EU states could only qualify for support from the European Stability Mechanism if they ratified the Fiscal Compact. ${ }^{50}$

Among other reforms, the Fiscal Compact altered the European Union's approach by emphasizing the judicial enforcement of austerity. Whereas the Maastricht regime had left considerable discretion in the hands of the Council of Ministers and Commission, the Fiscal Compact requires signatory states to enshrine a structurally balanced budget rule and an automatic debt brake in domestic law, so that national courts can enforce them. ${ }^{51}$ The Fiscal Compact demands ${ }^{52}$ that the

Regulation 472/2013, 2013 O.J. (L 104) 1 (EU); Council Regulation 473/2013, 2013 O.J. (L 140) 1 (EU).

46. Steven Erlanger, Sarkozy and Merkel Push for Changes to Europe Treaty, N.Y. TIMES (Dec. 5, 2011), http://www.nytimes.com/2011/12/06/world/europe/leaders-piecetogether-an-effort-to-keep-the-euro-intact.html.

47. See Ian Traynor et al., David Cameron Blocks EU Treaty with Veto, Casting Britain Adrift in Europe, GUARDIAN (Dec. 9, 2011, 3:34 PM), http:/www.theguardian.com/world/ 2011/dec/09/david-cameron-blocks-eu-treaty.

48. Formally, the Treaty on Stability, Coordination, and Governance in the Economic and Monetary Union, Feb. 1, 2012.

49. See Peter Spiegel, Victory for Merkel Over Fiscal Treaty, Fin. TIMES (Jan. 30, 2012, 11:25 PM), http://www.ft.com/int//cms/s/0/9068548a-4b68-1 le1-b980-00144feabdc0.html\# axzz3TB8TBZqQ. The treaty was signed at the EU summit on March 2, 2012. See also Quentin Peel et al., Eurozone States Sign up to Fiscal Pact, Fin. Times (March 2, 2012, 12:03 PM), http://www.ft.com/intl/cms/s/0/18ca1e80-6455-11e1-b50e-00144feabdc0.html\# axzz3TB8TBZqQ.

50. Treaty Establishing the European Stability Mechanism, Feb. 1, 2012, recital (5) (stating, "It is acknowledged and agreed that the granting of financial assistance in the framework of new programmes under the ESM will be conditional, as of 1 March 2013, on the ratification of the TSCG by the ESM Member concerned").

51. See TSCG supra note 3, art. 3(1).

52. See Id. art. 3(2). 
balanced budget rules be entrenched in national law, "through provisions of binding force and permanent character, preferably constitutional, or otherwise guaranteed to be fully respected and adhered to throughout the national budgetary processes." This provision seeks to enforce fiscal policy at the national level by requiring Member States to provide a legal basis for litigation to enforce balanced budget rules before national courts.

Harnessing national courts to enforce EU fiscal policy rules follows a well-established pattern in EU governance that I have labeled Eurolegalism. ${ }^{53}$ As in other policy areas, the European Union is seeking to make up for its lack of a strong centralized administrative apparatus or large central budget by leveraging domestic courts to pursue its policy objectives. Moreover, the Treaty provides for another tier of judicial enforcement by providing the ECJ with a role in ensuring that Member States actually put in place the balanced budget rule enforcement mechanisms demanded by Article 3(2). ${ }^{54}$ Article 8(1) of the Fiscal Compact states that if any state signatory to the agreement concludes that another state has failed to comply with Article 3(2), the concluding state can raise the matter before the ECJ and that, "the judgment of the Court of Justice shall be binding on the parties to the proceedings, which shall take the necessary measures to comply with the judgment within a period to be decided by the Court of Justice." 55

In a broad sense, the Fiscal Compact seeks to impose a system similar to the one that emerged from the bottom up in the United States from the 19th Century. In both cases, Member States embed balanced budget rules in state law (in forty-nine out of fifty states in the United States and twenty-five out of twenty-eight states in the European Union). The paths taken to arrive at these rules and the institutional context that surrounds them, however, differ in important ways. In the United States, the federal government let states default, and then states imposed balanced budget rules on themselves to win the confidence of lenders. ${ }^{56}$ In contrast, the European Union established a

53. See KELEMEN, supra note 9 , at 8.

54. See TSCG, supra note 3 , art. 3(2).

55. Finally, the Fiscal Compact provides for a second level of ECJ oversight. If a Party to the Treaty finds that another Party has failed to an ECJ judgment in a ruling pursuant to Art. 8(1), then, "it may bring the case before the Court of Justice and request the imposition of financial sanctions following criteria established by the European Commission in the framework of Article 260 of the Treaty on the Functioning of the European Union. If the Court of Justice finds that the Contracting Party concerned has not complied with its judgment, it may impose on it a lump sum or a penalty payment appropriate in the circumstances and that shall not exceed $0,1 \%$ of its gross domestic product." TSCG, supra note 3, art. 8(1)-(2).

56. See Fabbrini, supra note 19, at 28. 
bailout mechanism for states, but forced them to adopt balanced budget rules as a condition of access to bailout funds. As discussed in the next section, these background conditions, along with the specific character of the balanced budget rules introduced in the United States, have profound implications for their effectiveness.

\section{WILL THE FISCAL COMPACT WORK?}

With the new regime of fiscal governance described above now in place, questions concerning its ability to work will be answered. Will the domestically entrenched and "legally enforceable" balanced budget rules required by the Fiscal Compact discourage states from building up unsustainable deficits while simultaneously enabling them to borrow at reasonable rates when necessary? In short, will the European Union's effort to judicialize fiscal policy succeed? Unfortunately, since the Fiscal Compact only took effect in January 2013, and a number of states only ratified it in 2014, so it remains far too early for any definitive assessment of its impact.

Although it is too early for a full assessment of the Fiscal Compact's effectiveness, to date, there are few signs that the compact is working. In the words of Daniel Gros and Cinzia Alcidi, "All this legal apparatus seems to have had little impact on actual fiscal policy-making."57 A number of Member States' budgets seem to violate the terms of the Fiscal Compact, yet the European Commission treats these budgets as acceptable ${ }^{58}$ and domestic courts have not strictly enforced compliance with the Fiscal Compact's balanced budget rules. Rather, courts have balanced enforcement of these rules against the protection of other legal norms. ${ }^{59}$ In some instances, this balancing act has led national courts to strike down austerity measures that governments had imposed specifically to comply with the requirements of the Fiscal Compact because those measures violated other constitutionally protected values such as equal treatment and fundamental rights to employment

57. Daniel Gros \& Cinzia Alcidi, The Case of the Disappearing Fiscal Compact, in CEPS COMMENTARY 1 (Ctr. for European Policy Studies, Nov. 5, 2014).

58. See James Kanter, E.U. Gives 3 Nations More Time on Budgets, N.Y. TIMES, Nov. 29, 2014, at B2. As recently as November 2014, the European Commission refrained from imposing disciplinary measures on Belgium, France and Italy despite the fact that their budgets clearly violated the deficit and debt requirements of the Stability and Growth Pact. $I d$.

59. See Federico Fabbrini, The Euro-Crisis and the Courts: Judicial Review and the Political Process in Comparative Perspective, 32 BERKELEY J. INT'L LAW 64, 74-103 (2014) (discussing judicial review of provisions of the Fiscal Compact by national and EU courts). 
security. ${ }^{60}$ While it remains too early to conclude that the Fiscal Compact is ineffective based on the limited empirical evidence available to date, there are also convincing theoretical reasons to expect that the balanced budget rules in the Fiscal Compact will prove ineffective.

The European Union's approach to fiscal discipline seems to be based on the dominant understanding of how balanced budget rules work to limit sovereign debt. The literature on balanced budget rules in the U.S. suggests that these budget rules work better to constrain borrowing and limit borrowing costs the stricter their judicial enforcement mechanisms are. ${ }^{61}$ EU leaders' choices reflect this perspective, as they emphasize the empowerment of national and EU courts to strictly enforce deficit and debt limits. ${ }^{62}$ Thus, the Fiscal Compact requires states to adopt balanced budget rules, "through provisions of binding force and permanent character, preferably constitutional, or otherwise guaranteed to be fully respected and adhered to throughout the national budgetary processes" and to back them with an automatic "correction mechanism." 63

60. E.g., id. at 100 (discussing recent decisions of the Portuguese Constitutional Tribunal).

61. See, e.g., Henning Bohn \& Robert P. Inman, Balanced-budget Rules and Public Deficits: Evidence from the U.S. States, 45 CARNEGIE-ROCHESTER CONFERENCE SERIES ON PUB. POL. 13, 23 (1996) ("Appointed supreme courts may behave more like a government agency than a truly independent monitor of fiscal performance. Independently elected supreme courts, on the other hand, are free of direct gubernatorial or legislative influences and therefore hypothesized to be tougher monitors of fiscal policy."); Byron Lutz \& Glenn Follette, Fiscal Rules, What Does the American Experience Tell Us? 14 (Fed. Reserve Bd., Fin. \& Econ. Discussion Series Paper No. 38, 2012) (“[S]trong budget rules states persistently maintain a stronger fiscal position than weak rule states").

62. Many scholars have drawn lessons for the Eurozone from the literature on U.S. state balanced-budget rules. See Jürgen von Hagen \& Barry Eichengreen, Federalism, Fiscal Restraints and European Monetary Union, 86 AM. ECON. REV. 134-35 (1996) (arguing that borrowing limits of U.S. states were not set for the purpose of stabilizing the U.S. dollar); Barry Eichengreen \& Jürgen von Hagen, Fiscal Policy and Monetary Union: Federalism, Fiscal Restrictions and the No-Bailout Rule (Centre for Econ. Pol'y Research, Discussion Paper No. 1247, 1995)); Robert P. Inman, Do Balanced Budget Rules Work? U.S. Experience and Possible Lessons for the EMU 4 (Nat'l Bureau of Econ. Research, Working Paper No. 5838, 1996) (reviewing U.S. balanced budget rules to argue that they are an effective fiscal management tool); Robert P. Inman, Transfers and Bailouts: Enforcing Local Fiscal Discipline with Lessons from U.S. Federalism, in FISCAL Decentralization and the Challenge of HaRd Budget ConstrainTs 35 (Jonathan Rodden et al. eds., 2003) (reviewing fiscal performance of the U.S. state and local public sector to identify institutional features that promote responsible local budgeting); Michael D. Bordo et al., A Fiscal Union for the Euro: Some Lessons from History 7-10, (Nat'l Bureau of Econ. Research, Working Paper 17380, 2011) (analyzing U.S. establishment, evolution of the federal sub-national government relationships, and debt history including the development of bond markets and bailouts).

63. See TSCG, supra note 3 , art. 3(2). 
But as Terence Teo and I show, ${ }^{64}$ courts almost never enforce balanced budget rules, and fear of judicial enforcement does not explain their effectiveness. The European Union's emphasis on strictness and legal enforceability is misplaced because it is not courts, but the bond markets, that provide the enforcement threat behind balanced budget rules. And for bond markets, it is the clarity of the balanced budget rules that matters, not their judicial enforceability.

To understand the role that a clear balanced budget rule can play in restraining excessive deficit and debt, one must first understand why bond markets often fail to restrain excessive borrowing. All too often, bond markets allow a state to borrow at relatively low rates, until revealed information or an institutional panic spikes borrowing costs and renders the state insolvent. As Teo and I put it, "[i]nstead of playing a helpful role deterring the accumulation of excessive debt, markets often react too late and then so forcefully that they help drive states to default." 65 Balanced budget rules that are sufficiently clear can help overcome this problem by creating a focal point that generates a shared expectation among investors of the point at which other investors will punish the sovereign by demanding higher rates on its debt. ${ }^{66}$

This shared expectation is crucial, because investors care not only about a state's economic fundamentals, but also about whether they believe other bond buyers will continue to finance the state's debt at reasonable rates. ${ }^{67} \mathrm{~A}$ clear balanced budget rule can serve as a coordinating device for bond markets by providing a focal point or fiscal "red line," the crossing of which would be evident to all investors and which would trigger all to demand much higher yields on sovereign debt. ${ }^{68}$ Eager to avoid this coordinated market punishment, sovereigns will seek to avoid violating the balanced budget rule in the first place. However, bond markets can only play this disciplining role where balanced budget rules have sufficient clarity such that it is obvious to investors when the rules are broken. To support this theoretical claim, we demonstrate empirically that the effectiveness of balanced budget rules in the U.S. in fact does depend on their clarity, not on the strictness of their judicial enforcement mechanisms. 69

64. Kelemen \& Teo, supra note 8 , at 356.

65. Id. at 357 .

66. Id.

67. Investors care about what they believe other investors will do because a state's solvency is, in part, a self-fulfilling prophecy: as long as bond markets are willing to purchase sovereign bonds at reasonable yields, the state can remain solvent.

68. Investors' expectations of the behavior of other investors are crucial in this model. The solvency of a state depends not only on its economic fundamentals, but also on the willingness of creditors to hold its bonds.

69. Kelemen \& Teo, supra note 8 , at $362-365$. 
This analysis suggests that the balanced budget rules in the Fiscal Compact lack the clarity that would be necessary for them to serve as a focal point for bond markets. In fact, precisely what would constitute a balanced budget under the terms of the Fiscal Compact is extremely vague and subject to interpretation. The language of Fiscal Compact concerning balanced budgets starts out clearly enough, stating, "The budgetary position of the general government . . . shall be balanced or in surplus."70 But then come the qualifiers. In fact, the Fiscal Compact does not require states to balance their budgets on an annual basis but only to maintain "structurally balanced" budgets, which are balanced across the multiyear business cycle. The Fiscal Compact becomes truly abstruse when determining whether a budget is structurally balanced, and is worth quoting at length:

[T] he [balanced budget] rule under point (a) shall be deemed to be respected if the annual structural balance of the general government is at its country-specific medium-term objective, as defined in the revised Stability and Growth Pact, with a lower limit of a structural deficit of $0,5 \%$ of the gross domestic product at market prices. The Contracting Parties shall ensure rapid convergence towards their respective mediumterm objective. The time-frame for such convergence will be proposed by the European Commission taking into consideration country-specific sustainability risks. Progress towards, and respect of, the medium-term objective shall be evaluated on the basis of an overall assessment with the structural balance as a reference, including an analysis of expenditure net of discretionary revenue measures, in line with the revised Stability and Growth Pact. ${ }^{71}$

Investors would be hard pressed to find a clear fiscal red line in the opaque language of the Fiscal Compact. Not only is the Treaty's concept of structurally balanced budget subject to interpretation, the Treaty also allows for exceptions to even this fuzzy rule. States may "temporarily deviate" from the budget rules in "exceptional circumstances,"72 which the Treaty defines as, "the case of an unusual event outside the control of the Contracting Party concerned which has a major impact on the

70. TSCG, supra note 3, art. 3(1)(a).

71. Id. art. $3(1)(\mathrm{b})$.

72. Id. art. $3(1)(\mathrm{c})$. 
financial position of the general government or to periods of severe economic downturn."73 It is far from clear what exactly constitutes a cyclically adjusted, structurally balanced budget or what might constitute "exceptional" circumstances. Therefore, just what constitutes a violation of the European Union's balanced budget rules will be subject to lengthy, and highly political, debates.

National Parliaments must settle these debates. The domestic measures put in place to implement requirements of the Fiscal Compact have tended to empower Parliaments to determine when an emergency situation exists that would justify a derogation from balanced budget rules. In turn, a government's majority in parliament will determine whether the government is justified in violating balanced budget rules. ${ }^{74}$ National courts may review decisions by governments and parliaments to derogate from balanced budget rules, but the experience of judicial review of such questions in the European Union to date, and historically in the United States, suggests that we should expect courts to take a largely deferential approach. ${ }^{75}$ Finally, experience to date suggests that EU institutions will also grant Member States considerable flexibility in deviating from the balanced budget requirements of the SGP and the Fiscal Compact. ${ }^{76}$

Finally, aside from their lack of clarity, the European Union's balanced budget rules are likely to fail because the literature on fiscal federalism suggests that bondholders will only discipline excessive state borrowing and discourage the accumulation of unsustainable debts if they do not anticipate that insolvent states would be bailed out by the

73. Id. art. $3(3)(\mathrm{b})$.

74. See Giacomo Delledonne, A Legalization of Financial Constitutions in the EU? Reflections on the German, Spanish, Italian and French Experiences, in THE CONSTITUTIONALIZATION OF EUROPEAN BUDGETARY CONSTRAINTS 194 (Maurice Adams et al. eds., 2014) (discussing reforms in Germany, Spain and Italy that empower parliamentary majorities to declare when derogations from balanced budget rules and debt brakes are warranted).

75. See Richard Briffault, Foreword: The Disfavored Constitution: State Fiscal Limits and State Constitutional Law, 34 RUTGERS L. J. 907, 939-940 (2003) (discussing the deferential posture U.S. courts have taken to enforcing state balanced budget rules); Fabbrini, supra note 19, at 22 (discussing the largely deferential posture national courts have taken to enforcing the Fiscal Compact's balanced budget rules); see also Delledonne, supra note 74 , at $195-96$ (discussing the U.S. experience).

76. See generally Counsel Regulations and Directives, supra note 45. Also note, regarding the possibility of review by the European Court of Justice provided in the Fiscal Compact, that the European Commission is not permitted to bring enforcement action against states. Rather, only Member State parties to the TSCG are empowered to bring enforcement action against one another. More than five decades of experience with enforcement actions before the ECJ confirm that Member States almost never bring enforcement actions against one another. See also sources cited supra note 42. 
federal government. ${ }^{77}$ Thus, in the United States, the fact that the federal government had established a credible commitment to not bail out state governments provided a crucial support for the efficacy of state balanced budget rules. ${ }^{78}$ By contrast, if bond markets expect the federal center to bail out insolvent states, they may be happy to ignore any fiscal rules and continue lending even when debts appear unsustainable. Indeed, the anticipation of bailouts helps explain why Greek borrowing costs remained so low after the introduction of the euro-even as Greece's debt-to-GDP ratio grew to dangerous levels. ${ }^{79}$ As noted above, the new regime of fiscal governance put in place in response to the Eurozone crisis includes a permanent bailout fund-the ESM. The establishment of the ESM, a permanent bailout mechanism, is likely to undermine the efficacy of bond market discipline, regardless of the level of clarity of balanced budget rules.

\section{CONCLUSION}

We can draw broader lessons about the relationship between law, fiscal federalism, and austerity from the foregoing analysis of the European Union's recent experience. The Fiscal Compact has only been in force since January 2013, and it is too early to draw definitive conclusions. But already the EU experience underscores a few important themes when considered alongside those of other federal systems.

The central overriding lesson is that the judicial enforcement of fiscal discipline is unlikely to succeed. The experience of the European Union to date and the experience of the United States historically suggest that courts cannot be relied on to act as enforcers of fiscal discipline. Courts generally take a deferential posture vis-à-vis elected officials in the realm of fiscal policy, and when they consider the enforcement of balanced budget rules, they balance these requirements against other legal norms and rights that may lead them to reject austerity measures. Thus if national leaders want to impose austerity on themselves or one another, they should not look to the courts to enforce fiscal rules.

Second, if lawmakers in the European Union or elsewhere wish to deploy balanced budget rules as a mechanisms to constrain excessive state borrowing, they must design these rules with a better understanding of how the rules actually work and under what

77. See Bordo et al., supra note 62, at 6; see also Mark Hallerberg, Fiscal Federalism Reforms in the European Union and the Greek Crisis, 12 EUR. UNION POL. 127, 131 (2010).

78. Kelemen \& Teo, supra note 8, at 365.

79. Jones, supra note 32. 
conditions they can be effective. First, to be effective, balanced budget rules must be clear. As discussed above, it is bond markets and not courts that enforce balanced budget rules, and bond markets can only effectively enforce these rules where they are clear. The balanced budget rules in the Fiscal Compact are far too ambiguous to serve as an effective focal point for enforcement by bond markets.

But in the EU context, the solution cannot simply be to impose clearer, nominal balanced budget rules on Eurozone members. In practice, it would be untenable for the European Union to adopt national balanced budget rules clear enough to work effectively without dramatically increasing the EU budget and its capacity to engage in countercyclical policies. U.S. states can only sustain their relatively clear nominal balanced budget rules (which lead them to impose procyclical austerity measures during recessions) because the federal government can engage in countercyclical fiscal policy-using deficit spending to stimulate the economy during economic downturns. Imposing such nominal balanced budget rules on Member States remains economically undesirable and politically unsustainable in the European Union, where the "federal" budget remains tiny and incapable of supporting significant countercyclical policies in periods of recession. Already, the recent electoral victory of the radical, anti-austerity Syriza party in Greece suggests that the imposition of austerity at the Member State level in the absence of significant countercyclical policies from the EU level is not politically tenable over the long-term.

Finally, however clear the balanced budget rules adopted by states, bond markets will only act to enforce these effectively if the federal government has established a credible commitment not to bail out insolvent states. Most likely, the only way to make that commitment credible is to actually allow one or more Member States to default as the United States did in the early $1840 \mathrm{~s}$. Whether EU leaders are willing to countenance the risks associated with the default and possible exit from the Eurozone of a Member State remains to be seen. But clearly, the defiant Greek government led by the leftist, anti-austerity Syriza party is providing them with a tempting target. In the months since Syriza came to power on promises of ending Eurozone imposed austerity, its creditors have mostly held the line, demanding that Greece continue to meet the conditions attached to its bailout loans. ${ }^{80}$ Key creditors such as Germany have indicated that if Greece is unwilling to meet those

80. Karl Navarra, Rainer Buergin, and Paul Tugwell, Germany Rejects Loan Request Saying Greece Must Meet Conditions, BloomBERG, Feb. 19, 2015, available at http://www. bloomberg.com/authors/AOXQCpopcGQ/paul-tugwell. 
conditions, they may allow them to default and exit the Eurozone despite the risks involved. ${ }^{81}$

81. Nikolaus Blome, Giorgos Christides, Christian Reiermann and Gregor Peter Schmitz, Grexit Grumblings: Germany Open to Possible Greek Eurozone Exit, SPIEGEL ONLINE INTERNATIONAL (Jan. 5, 2015), available at http://www.spiegel.de/international/ europe/merkel-and-germany-open-to-possible-greek-euro-zone-exit-a-1011277.html. 